\title{
CORRELATION BETWEEN \\ PREPARATION DOING TASKS OF LECTURING AND PREPARATION FACING FINAL EXAM (A Study of Students' Habit in Learning)
}

\author{
Sudiyono $^{1}$ \\ ${ }^{1}$ IKIP Siliwangi \\ ${ }^{1}$ sudiyonostkipslw@gmail.com
}

\begin{abstract}
This research was about correlation between doing tasks of lecturing ( $\mathrm{X}$ variable) and doing preparation facing final exam (Y variable). Data used in this research was the students of English Program of STKIP Siliwang Bandung, Semester VII academic year 2015-2016. The research concerns to find out the correlation between two variables observed, preparation doing tasks of lecturing and preparation facing the final exam. To achieve the most accurate results of this research, here researcher choose correlational method. The results of this research shown mean of $\mathrm{X}$ variable was 4.30 and mean of $\mathrm{Y}$ variable was 4.36. They mean that both activities (doing tasks of lecturing ( $\mathrm{X}$ variable) and doing preparation facing final exam (Y variable) are high/good. But, the correlation between them was low/not significant, it was indicated by 0,23 scale of Likert.
\end{abstract}

Keywords: Lecturing, Tasks, Final Exam

\section{INTRODUCTION}

In lecturing, students have to do some tasks such as; home works, making summaries, looking for references, and etc. Those tasks were responded by the students and they would do what their lecturers bid at home and collect the results of their home works on the limited time as their lecturers gave. Meanwhile final exam must be faced for any subjects were contracted on each semester before he/she is sated pass of their compulsories.

To get good scores from the lecturers, students must do their tasks in lecturing by giving all tasks on time, doing tasks seriously, understanding every task given, self confident, and believe that all tasks are useful for him/her.

Meanwhile, to pass the final exam for all subjects tested, students must prepare themselves by reading the subjects' materials, having well organized study, to resume parts of the subjects, preparing special time for learning, and having enough references for every subject. For both of tasks and final exam, students must do the same important efforts in order to be success with. This research is about how students usually make and collect the lecturing tasks and how they are facing the final exam in the end of the semester. Empirically, students those who are diligent to do their lecturing tasks given by the lecturers and collect them right on time, usually they get better scores in final exam during they're joining their activities of lecturing. That why this research will be focusing on the correlation between both doing tasks of lecturing and preparation to face the final exam of the end of semester.

As the research focus mentioned above, objectives of the research can be formulated as follow:

a. To describe the students' efforts of doing their tasks of lecturing. 
b. To describe the students' efforts in facing their final exam.

c. To find out the correlation of both activities above.

Benefits of this research lead us to understand how important for the students to do their tasks of lecturing, its' as important as their preparing to face the final exam. Beside, by studying this research we can know how far the efforts of the students to do such those two activities above and how the results are. And last, we are going to know how is the correlation of both activities, especially in the place where the research was done.

\section{Tasks of Lecturing}

Tasks of lecturing and exam are parts of the lecturing activities as a whole. The main aim of those two activities most directed to know the results of lecturing activities being done (outcome).

Both tasks and final exam in lecturing are as compulsories for the students to have pass into higher level of class/standards. Beside, these two activities can be 'measured' for the importance of improving teaching-learning activity.

Tasks of lecturing for the students are written summaries of the lecture materials, make mind maps of the information, answer question about the information, prepare for a quiz on the information, make up test question from the information, writing in a journal. A good preparation in doing tasks of lecturing could be indicated by;

1. Giving tasks of lecturing on time is one of discipline character that is shown by the students. Teachers or lecturers should usual their students to make/give all tasks of lecturing on time, this action will train the affective domain of students becomes better, beside it will push their scores of tasks up.

2. Making tasks seriously means making tasks in full concentration and supposing what is done is really important. It refers to 'serious' means concerned with work or important matters rather than play or trivialities.

3. Understanding is meaningful learning. It is usually contrasted with rote learning (memorization), although it is also distinct from skill application and generic skill application - Instructional-Design Theories Site, Modul 6.

4. Self confident means do something with full belief, behaving calmly because you have no doubts about your ability or knowledge. Cambridge Dictionary

5. Tasks were useful, a good preparation to do the tasks of lecturing by students will be realized if students are conscious that such compulsories are useful and important.

\section{Preparation of Facing Final Exam}

To make a good preparation in facing final examination a student should be doing reading all subjects, having a well organized study, making summary of subjects, preparing enough time to learn, and having enough references

1. Reading all subjects is one of several good acts in facing all kinds of exam, including final examination for students of university/college. This so reasonable because Why is reading important? It is how we discover new things. Books, magazines and even the Internet are great learning tools which require the ability to read and understand what is read. A person who knows how to read can educate themselves in any area of life they are interested in. We live in an age where we overflow with information, but reading is the main way to take advantage of it.

2. Organized study, the importance of an organized study is

a. Helps eliminate confusion as a clear action plan emerges with a little thinking and planning. It also imparts a sense of direction. One feels organized and in command because a proper plan will involve thorough understanding of one's course or syllabus. 
b. Set targets are like milestones to be crossed. The achievement of each target provides motivation to achieve another. Very soon one starts enjoying the process because the concepts become clearer and understanding improves.

c. Regular studies reduce the level of stress. One's priorities become clear and the requisite level of importance and effort can be directed to the learning of each subject. Work does not get accumulated and hence there is no need to study at unearthly hours. This also safeguards one's physical and mental health.

d. Studying at regular hours increases concentration and inculcates a sense of discipline. No panic buttons need to be pressed any more.

e. One can find time for leisure activities and recreation to refresh one's mind and still achieve the set targets.

3. Making summary, The goal of writing a summary of an article, a single chapter or a whole book is to offer as accurately as possible the full sense of the original, but in a more condensed form. A summary restates the author's main point, purpose, intent and supporting details in your own words.

4. Preparing time, setting up an exam study timetable can be a very effective time management strategy. Exams test more than just your content knowledge, they also test your ability to manage your time effectively (before and during the exam). In order to succeed in your exams, you should allocate enough study time to prepare effectively for all your subjects.

5. Enough information equals with enough preparation, so information will give us everything in preparing something we need, belong in facing an exam.

\section{METHOD}

Research design refers to Tavakoli (2012) in Kaswan, et.al (2015: 14) is the arrangement of conditions for collection and analysis of data in a manner that aims to combine relevance to the research purpose. In fact the research design is the conceptual structure within which research is conducted; it constitutes the blueprint for the collection, measurement, and analysis of data. As such, the design includes an outline of what the researcher will do from the formulation of the research questions and hypotheses to reporting the research findings. In this research, researcher uses the quantitative research design.

As Sigh stated (2007: 99) that method is a style of conducting a research work which is determined by the nature of the problem (Kaswan, et.al., 2015: 14). The research concerns to find out the correlation between two variables observed, doing tasks and preparation facing the final exam. To achieve the most accurate results of this research, here researcher choose correlational method.

Population of this research is a group of students of English Department STKIP Siliwangi Bandung, semester VII, academic year 2015-2016. Total population there are 352 students. While the sample of this research was taken about $15 \%$ randomly chosen from the population, they are 52 students.

1. Data collection

The data is collected from the sample of the population using randomly technique. The technique of data collecting is done by observation and giving questionnaires to the sample of the population.

2. Analysis

The analysis of the data use two approaches, such as partial analysis and correlational analysis. For partial analysis is:

$$
\text { Mean } X=\sum \mathbf{f x} / \mathbf{n}
$$




\section{Mean $Y=\sum f y / n$}

Mean score of each variable $\mathrm{X}$ and $\mathrm{Y}$, which is $\mathrm{X}$ indicates activity of doing tasks, $\mathrm{Y}$ is preparation facing final exam, and ' $n$ ' is total sample. In doing partial analysis it is aimed to know each variable condition by giving scores to the mean of each variable. Criteria of scoring to each variable is as follow:

\begin{tabular}{cc}
\hline Mean score & Criteria \\
\hline $.00-1.49$ & Very low \\
\hline $1.50-2.49$ & Low \\
\hline $2.50-3.49$ & Moderate \\
\hline $3.50-4.49$ & High \\
\hline $4.50-5.50$ & Very high
\end{tabular}

For correlational analysis, it uses the formula to find out the coefficient between $\mathrm{X}$ variable and $\mathrm{Y}$ variable, such Pearson Product Moment Correlation Coefficient is

2002: 186)

$$
\mathbf{r x y}=\underline{\mathbf{n}\left(\sum \mathbf{x y}\right)-\left\{\left(\sum \mathbf{x}\right)\left(\sum \mathbf{y}\right)\right\}} \quad \text { (Burn, 1995:186 in Sudiyono, }
$$

$$
\sqrt{ }\left[\left\{\mathbf{n} \sum \mathbf{x}^{2}-\left(\sum \mathbf{x}\right)^{2}\right\}\left\{\mathbf{n} \sum \mathbf{y}^{2}-\left(\sum \mathbf{y}\right)^{2}\right\}\right]
$$

To test the coefficient of significant, it is used formula:

$$
=0.23
$$

$$
\mathbf{T}=\mathbf{r} \sqrt{ }(\mathbf{N}-2): \mathbf{1} \sqrt{ }\left(\mathbf{N}-\mathbf{r}^{2}\right)
$$

\section{RESULTS AND DISCUSSION}

\section{Results}

This part included finding of the research that was conducted to students' activities of doing their tasks of lecturing; students' activities in facing final exam; and the correlation of those both activities.

\section{Activities of doing tasks}

\section{Mean of X variable}

\begin{tabular}{llc}
\hline No & \multicolumn{1}{c}{ Doing tasks } & $\mathbf{X}$ \\
\hline 1 & $\begin{array}{l}\text { Giving tasks on } \\
\text { time }\end{array}$ & 4.13 \\
\hline 2 & Doing tasks serious & 4.33 \\
\hline 3 & Understanding & 3.69 \\
\hline 4 & Self confident & 4.19 \\
\hline 5 & Tasks were useful & 4.13 \\
\hline & $\begin{array}{l}\text { Mean of } X=\sum \mathbf{X}: \\
\mathbf{5}\end{array}$ & $\mathbf{4 . 3 0}$ \\
& & \\
\end{tabular}

Analysis of Normal Distribution for $\mathbf{X}$ variable 
Next step is to find out the mean and standard deviation of $\mathrm{X}$ variable. The steps can be shown as follow:

a. To range $\mathrm{X}$ variable data (r) using formula:

$\mathrm{r}=\mathrm{H}-\mathrm{L}$

$\mathrm{r}=25-16$

$\mathrm{r}=9$

b. To make maximum class interval (C) using formula:

$\mathrm{C}=1+3.3 \log \mathrm{n}$

$\mathrm{C}=1+3.3 \log 52$

$\mathrm{C}=1+3.3(1.7160)$

$\mathrm{C}=6.6628 \longrightarrow 6$

c. Making length of class (L), using formula:

$\mathrm{L}=\mathrm{r}: \mathrm{C}$

$\mathrm{L}=9 ; 6$

$\mathrm{L}=1.50$

d. Making table of distribution of frequency for $\mathrm{X}$ variable:

\begin{tabular}{cccccc}
\hline No & Scores & $\mathbf{X}$ & $\mathbf{F}$ & $\mathbf{F X}$ & $\mathbf{F X}^{\mathbf{2}}$ \\
\hline 1 & $25-24$ & 24.5 & 3 & 73.5 & $1,800.75$ \\
\hline 2 & $23-22$ & 22.5 & 10 & 225 & $5,062.5$ \\
\hline 3 & $21-20$ & 20.5 & 23 & 471.5 & $9,665.75$ \\
\hline 4 & $19-18$ & 18.5 & 12 & 222 & 4,107 \\
\hline 5 & $17-16$ & 16.5 & 4 & 66 & 1,089 \\
\hline & Total & & $\mathbf{5 2}$ & $\mathbf{1 0 5 8}$ & $\mathbf{2 1 , 7 2 5}$
\end{tabular}

From the table above, we can see:

$\sum \mathrm{fX}=1,058$

$\sum \mathrm{fX}^{2}=21,725$

$\sum \mathrm{f}=52$

e. Mean of $\mathrm{X}$ variable:

$\mathrm{X}=\sum \mathrm{fx} / \mathrm{n}$

$\mathrm{X}=1,058: 52$

$X=20,34$

f. Standard deviation:

$\mathrm{SD}=\sqrt{ }\left[\left(\sum \mathrm{fy}^{2}: \mathrm{n}\right)-\left(\sum(\mathrm{fx}: \mathrm{n})^{2}\right)\right] \quad$ (Burn, 1995: 39 in Sudiyono, 2002: 19)

$\mathrm{SD}=\sqrt{ }\left[(21,725: 52)-(1,058: 52)^{2}\right]$

$\mathrm{SD}=\sqrt{[417.79-413.96]}$

$\mathrm{SD}=\sqrt{3} .83$

$\mathrm{SD}=1.96$

Preparation facing final exam

Mean of Y variable

\begin{tabular}{llc}
\hline No & \multicolumn{1}{c}{ Facing exam } & Y \\
\hline 1 & $\begin{array}{l}\text { Reading all } \\
\text { subjects }\end{array}$ & 3.23 \\
\hline 2 & Organized study & 3.58 \\
\hline 3 & Making summary & 3.94
\end{tabular}




\begin{tabular}{lll}
\hline 4 & Preparing time & 3.59 \\
\hline 5 & Enough references & 3.75 \\
\hline & $\begin{array}{l}\text { Mean of } \mathbf{Y}=\sum \mathbf{Y}: \\
\mathbf{5}\end{array}$ & $\mathbf{3 . 6 2}$ \\
&
\end{tabular}

\section{Analysis of Normal Distribution for Y variable}

Next step is to find out the mean and standard deviation of Y variable. The steps can be shown as follow:

g. To range $\mathrm{Y}$ variable data (r) using formula:

$\mathrm{r}=\mathrm{H}-\mathrm{L}$

$\mathrm{r}=25-14$

$\mathrm{r}=11$

h. To make maximum class interval (C) using formula:

$\mathrm{C}=1+3.3 \log \mathrm{n}$

$\mathrm{C}=1+3.3 \log 52$

$\mathrm{C}=1+3.3(1.7160)$

$\mathrm{C}=6.6628 \longrightarrow 6$

i. Making length of class (L), using formula:

$\mathrm{L}=\mathrm{r}: \mathrm{C}$

$\mathrm{L}=11 ; 6$

$\mathrm{L}=1.83 \Rightarrow 1.0$

j. Making table of distribution of frequency for Y variable

\begin{tabular}{cccccc}
\hline No & Scores & Y & F & FY & FY $^{2}$ \\
\hline 1 & $25-24$ & 24.5 & 2 & 49 & $1,200.5$ \\
\hline 2 & $23-22$ & 22.5 & 9 & 202.5 & $4,556.25$ \\
\hline 3 & $21-20$ & 20.5 & 14 & 287 & $5,883.5$ \\
\hline 4 & $19-18$ & 18.5 & 16 & 296 & 5,476 \\
\hline 5 & $17-16$ & 16.5 & 9 & 148.5 & $2,450.25$ \\
\hline 6 & $15-14$ & 14.5 & 2 & 29 & 420.5 \\
\hline & Total 2 & & $\mathbf{5 2}$ & $\mathbf{1 , 0 1 2}$ & $\mathbf{1 9 , 9 8 7}$
\end{tabular}

From the table above, we can see:

$\sum \mathrm{fY}=1,012$

$\sum f Y^{2}=19,987$

$\sum \mathrm{f}=52$

k. Mean of Y variable:

$\mathrm{Y}=\sum \mathrm{fy} / \mathrm{n}$

$\mathrm{Y}=1,012: 52$

$\mathrm{Y}=19.46$

1. Standard deviation:

$\mathrm{SD}=\sqrt{ }\left[\left(\sum \mathrm{fy}^{2}: \mathrm{n}\right)-\left(\sum(\mathrm{fy}: \mathrm{n})^{2}\right)\right]$

$\mathrm{SD}=\sqrt{ }\left[(19,987: 52)-(1,012: 52)^{2}\right]$

$\mathrm{SD}=\sqrt{[384.36-378.69]}$

$\mathrm{SD}=\sqrt{5} .67$

$\mathrm{SD}=2.38$

Correlation between doing lecturing tasks and preparation facing final exam: 


\begin{tabular}{cccccc}
\hline No & \multicolumn{2}{c}{ Variable } & $\mathbf{X}^{\mathbf{2}}$ & $\mathbf{Y}^{\mathbf{2}}$ & $\mathbf{X Y}$ \\
\cline { 2 - 4 } $\mathbf{I}$ & $\mathbf{X}$ & $\mathbf{Y}$ & & & \\
\hline 1 & 23 & $\mathbf{I I}$ & $\mathbf{I V}$ & $\mathbf{V}$ & $\mathbf{V I}$ \\
\hline 2 & 22 & 20 & 529 & 484 & 506 \\
\hline 3 & 20 & 22 & 400 & 484 & 440 \\
\hline 4 & 20 & 17 & 400 & 289 & 340 \\
\hline 5 & 22 & 18 & 484 & 324 & 396 \\
\hline 6 & 22 & 19 & 484 & 361 & 418 \\
\hline 7 & 25 & 25 & 625 & 625 & 625 \\
\hline 8 & 20 & 23 & 400 & 529 & 460 \\
\hline 9 & 21 & 19 & 441 & 361 & 399 \\
\hline 10 & 24 & 18 & 576 & 576 & 432 \\
\hline 11 & 20 & 17 & 400 & 289 & 340 \\
\hline 12 & 17 & 22 & 289 & 484 & 374 \\
\hline 13 & 19 & 20 & 361 & 400 & 380 \\
\hline 14 & 20 & 20 & 400 & 400 & 400 \\
\hline 15 & 19 & 19 & 361 & 361 & 361 \\
\hline 16 & 19 & 18 & 361 & 324 & 342 \\
\hline 17 & 21 & 17 & 441 & 289 & 357 \\
\hline 18 & 20 & 18 & 400 & 324 & 360 \\
\hline 19 & 21 & 21 & 441 & 441 & 441 \\
\hline 20 & 22 & 19 & 484 & 361 & 418 \\
\hline 21 & 21 & 20 & 441 & 400 & 420 \\
\hline 22 & 19 & 21 & 361 & 441 & 399 \\
\hline 23 & 20 & 17 & 400 & 357 & 340 \\
\hline 24 & 21 & 19 & 441 & 441 & 399 \\
\hline 25 & 20 & 16 & 400 & 256 & 320 \\
\hline 26 & 21 & 22 & 441 & 441 & 462 \\
\hline 27 & 20 & 19 & 400 & 361 & 380 \\
\hline 28 & 22 & 20 & 484 & 400 & 440 \\
\hline 29 & 20 & 14 & 400 & 196 & 280 \\
\hline 30 & 20 & 20 & 400 & 400 & 400 \\
\hline 31 & 21 & 22 & 441 & 484 & 462 \\
\hline 32 & 19 & 21 & 361 & 441 & 399 \\
\hline 33 & 19 & 20 & 361 & 400 & 380 \\
\hline 34 & 19 & 19 & 361 & 361 & 361 \\
\hline 35 & 19 & 17 & 361 & 289 & 323 \\
\hline 36 & 17 & 19 & 289 & 361 & 323 \\
\hline 38 & 20 & 20 & 400 & 400 & 400 \\
\hline 40 & 18 & 20 & 324 & 400 & 360 \\
\hline 41 & 17 & 17 & 324 & 289 & 306 \\
\hline 43 & 16 & 19 & 256 & 361 & 304
\end{tabular}




\begin{tabular}{cccccc}
\hline 45 & 21 & 19 & 441 & 361 & 399 \\
\hline 46 & 23 & 22 & 529 & 484 & 484 \\
\hline 47 & 22 & 20 & 484 & 400 & 440 \\
\hline 48 & 20 & 22 & 400 & 484 & 440 \\
\hline 49 & 20 & 17 & 400 & 289 & 340 \\
\hline 50 & 22 & 18 & 484 & 324 & 396 \\
\hline 51 & 22 & 19 & 484 & 361 & 418 \\
\hline 52 & 25 & 25 & 625 & 625 & 625 \\
\hline$\sum$ & $\mathbf{1 , 0 5 8}$ & $\mathbf{1 , 0 1 2}$ & $\mathbf{2 1 , 7 2 5}$ & $\mathbf{1 9 , 9 8 7}$ & $\mathbf{2 0 , 6 4 5}$
\end{tabular}

To find out the correlation, we uses formula as follow:

$$
\begin{aligned}
& \operatorname{rxy}=\frac{\mathrm{n}\left(\sum \mathrm{xy}\right)-\left\{\left(\sum \mathrm{x}\right)\left(\sum \mathrm{y}\right)\right\}}{\sqrt{ }\left[\left\{\mathrm{n} \sum \mathrm{x}^{2}-\left(\sum \mathrm{x}\right)^{2}\right\}\left\{\mathrm{n} \sum \mathrm{y}^{2}-\left(\sum \mathrm{y}\right)^{2}\right\}\right]} \\
& \operatorname{rxy} \quad=\frac{(52 \times 20,645)-(1,058 \times 1,012)}{\sqrt{ } 156900480} \\
& \operatorname{rxy} \quad=2,844: 12,526
\end{aligned}
$$

\section{Discussion}

From the research and data formulating, it was known that the activities of students to do their lecturing tasks (which were indicated by giving tasks to the lecturers on time; to organized their study; to understand all tasks given by lecturers for all subjects; feeling self confident in doing all tasks; and the understanding that making tasks from the lecturers were important for them) were good.

Partial analytically, it was found that the highest scores of doing lecturing tasks (X variable) was 25 and the lowest was 16 from the scoring scale from 1 to 25 . Mean of X variable was 4.30 from scale scores of 1 to 5. It was meant that category of students efforts in doing their tasks of all subjects in "good" category. It means that students" efforts in doing their tasks of all subjects in lecturing as a whole were good.

Partial analytically, it was found that the highest scores of preparation facing final exam (Y variable) was 25 and the lowest was 14 from the scoring scale from 1 to 25 . Mean of Y variable was 3.60 from scale scores of 1 to 5. It was meant that category of students efforts in preparing their final exam in "good" category. It means that students' efforts in preparing their final exam as a whole were good.

From data calculating it was found that correlation between $\mathrm{X}$ variable and $\mathrm{Y}$ variable was 0,23 . It's shown there is no significant correlation. Meanwhile, $\mathrm{X}$ variable effected $\mathrm{Y}$ variable in small percentage, it was only $3 \%$.

\section{CONCLUSION}

Refer to results of the research, researcher finally could conclude his research conclusion concerning with his focus of study as follow, 
a. The students' efforts of doing their tasks of lecturing was high/good. It was indicated by Mean of X variable was 4.30 from scale scores of 1 to 5 .

b. The efforts of students in preparing to face the final exam was high/good. It was indicated by Mean of $Y$ variable was 3.60 from scale scores of 1 to 5 .

c. The correlation of both efforts above were low/not significant, and there was little effect of doing tasks of lecturing to the preparation in facing the final exam. Correlation between $X$ variable and $Y$ variable was 0,23 . Meanwhile, $X$ variable effected $Y$ variable in small percentage, it was only $3 \%$.

\section{Suggestion}

It needs further research concern larger populations and range of places to find out more accurate result of such research, and it should be better if the result is followed by the reason why it can be.

The reasons why there was no significant correlation between doing lecturing tasks and preparation facing the final exam activity in this research is not impossible becoming contradiction for the other the same research with different places, times, and subjects/objects.

\section{ACKNOWLEDGMENTS}

The highest gratitude and thanks to Allah SWT for giving strength, health and motivation in finishing this. The writers say a lot of thank to everybody who support me all this time and unforgettable to my colleagues who have support us in various ways.

\section{REFERENCES}

Crowl, K. Thomas., 1996. Fundamentals of Educational Research - Second Edition. USA: Brown \& Benchmark Publisher.

Maxwell, Joseph A., 1996. Qualitative Research Design: An Interactive Approach. London: SAGE Publication.

McMillan James H. \& Schumacher Sally., 2001. Research in Education: A Conceptual Introduction. New York: Longman.

Simamora, Henry., 1999. Manajemen Sumber Daya Manusia - Edisi ke-2. Yogyakarta: Bagian Penerbitan Sekolah Tinggi Ilmu Ekonomi YKPN.

Sudiyono, 2002. Correlation between Students' Speaking Ability and Their Grammar Mastery. A Paper. Cimahi : STKIP Siliwangi.

Suparman, Eman. 2008. Penerapan Apresiasi pada Kegiatan Pembelajaran Pendidikan Agama Islam - Penelitian di SDN Sukagalih 2 Bandung. Bandung : Pokjawas PAI Kandepag Kota Bandung

Wiersma, Williams., 1991. Research Method in Education: An Introduction - Fifth Edition. Allyn and Bacon: The University of Toledo. 